\title{
NEED ANALYSIS ON ENGLISH TEACHING MATERIALS FOR ICT STUDENTS
}

\author{
Sri Diana \\ Polytechnic Negeri ATI Makassar, Indonesia \\ sridiana21@gmail.com \\ Musdalifah Mansur \\ Universitas Negeri Makassar, Indonesia \\ musdalifahippomansur@gmail.com
}

\begin{abstract}
The research aims to find out the English Materials need of the students of Genetic Computer School Singapore in Learning English. The quantitative and qualitative method were conducted in this research to describe the students' needs. In collecting the data, the researcher applied interview for lecturers and questionnaire for the students as the instrument of the research. There were two lecturers and thirty of second-semester students in the 2017-2018 academic year as participants in this research by conducting purposive sampling. The result of this research revealed that students of Information, Communication and Technology (ICT) mostly needed two skills in learning English. First, speaking skill that is to communicate in English and to present their final project exam. Second, writing skill is used to do their assignment and final report in English. Language element which is the most important and needed by the students is vocabulary, then followed by grammar. The interview result showed that in teaching English the lecturers do not have permanent syllabuses for four semesters and the existing materials are designed based on lecturers perception, it is not based on students needs. The information of this research as the recommendation for the institution that might be used as guidance to design the English syllabuses.
\end{abstract}

Keywords: English Teaching Materials, Need Analysis, ICT Students.

\section{A. INTRODUCTION}

nglish has the pivotal role as tool of communication in the global community. English
becomes as standard language for the people around the world. The people come
from different nationalities in various fields use English to communicate and understand each other. English is used not only in politics or foreign affair but also in educational system that English widely used as a medium for understanding each other. It happens to the students of Genetic Computer School (GCS) of Singapore which has affiliated with Universitas Negeri Makassar. The lecturers come from Singapore which commonly use English in teaching. Therefore, the students should master English.

Since 2008, Universitas Negeri Makassar (UNM) has affiliated with the GCS in Diploma Program by conducting two study programs, they are International Diploma in Computer Studies and International Higher Diploma in Computer Studies. The Curriculum was applied based on 
International standard and the students will get certificate that can be used to support their best future carrier abroad. This program refers to graduates of high school students and university students. In this study program, learning model was used in English and Indonesia as language instruction. This institution provides learning materials which used English. It indicates that students should master English. On the other hand, English become stands point in this institution. English as a compulsory subject for first semester students and GCS-UNM involved students in joining English course which is held once a week.

Based on pre observation, it showed that in teaching English the lecturers do not have permanent syllabus from the institution and the lecturer teaching English is not based on students need. The English teaching materials were designed by lecturers based on their perception. It becomes crucial to give attention to the stakeholder in this institution. By this research, the researcher tried to find out the English Materials need of the Genetic Computer School Singapore in Learning English. To collect information related to the materials which meet with the learning needs of learners, the design of the materials need to apply Need Analysis(Li, 2014). It can also be used as the basis for designing tests, compiling materials, designing teaching activities and evaluating strategies.

Need Analysis (NA) is essential for developing a course because "it forms a rational basis for all the other component of a systematic language curriculum" (Iwai, et al., 1999). It is supported by Brown (1995) who stated that the prominent of need analysis as an initial step to develop the curriculum. In addition, He also said that need analysis is the systematic collection and evaluation of all subjective and objective records important to outline and validate defensible curriculum purposes that fulfill the language mastering necessities of students within the context of particular establishment that have an impact on the learning and teaching state affairs.

According to John (1991) regards need analysis as the first step in curriculum design which can provide the validity and relevancy for curriculum design activities. Nunan (1994) also argues that "need analysis is a set of procedures for specifying the parameters of a course of study which include the criteria and rationale for learner, the sequencing and selection of course content, methodology, course length, and intensity and duration. According to Dudley Evans and St. John (1998) stated that need analysis is the process of determining how and what the course is. It is clear that need analysis is needed in designing course. 


\section{Sri D, Musdalifah M. Need Analysis on English Teaching Materials for ICT ...}

\section{B. REVIEW OF THE LITERATURE}

Need analysis has four models which recognize by some scholar; (1) Target Situation Analysis; (2) Present Situation Analysis; (3) Hutchinson and Waters Model; (4) Dudley-Evans and St John's Model of Need Analysis. Target Situation Analysis (TSA) focused on students' needs at the end of the language course (Robinson, 1991). Present Situation Analysis (PSA) showed the gap between the present and the target. PSA explores "to find out the language proficiency of the students when the language course begins and their strengths and weakness (Robinson: 1991). Hutchinson and Waters' model (1987) showed the need analysis model which divided into two parts: Target situation needs and learning needs. Target situation needs related to the learner 'necessities', 'lacks' and 'wants'. 'Necessities' are decided at the demand of the target situation. 'Lacks' are the gap between 'necessities' and the learner prior knowledge. 'Wants' are the learner needs which has no relationship between course which perceived by the teacher. Moreover, Dudley-Evans and St John's Model of need analysis provide personal information about the learners, language information about the target situation. Professional information about learners, learners' lack, Learners' needs from course, language learning needs, and the last how to communicate in the target needs.

Some previous research conducted need analysis to find out the students need in learning English, such as ;(Kaur et al., 2010) showed the research result that oral presentation, specialized vocabulary activities and topics relevant to the students' area of specialization was needed by students; Kim (2013) used need analysis to develop ESP course for engineering students in Korea; Li (2014) stated that the result of need analysis is helpful to set the teaching goals,

selecting textbook and teaching methods and as guidance to the course designer into designing English materials. Araminta and Halimi (2015) conducted need analysis to analyze the English needs of undergraduate engineering students at University in Indonesia and the result showed that the needs of students' English language were not significant. The result of their research recommended the institution should collaborate with the companies to collect information related to language use in the field of work.

As consequences of this situation, the main aim of the present study was to conduct a need analyses to know the students need in learning English. The information of the result of this result will be guidance for the lecturers to design English teaching materials for ICT students. 
Volume 4, Number 2, December 2018

\section{RESEARCH METHOD}

This research employed quantitative and qualitative method. The questionnaire was analyzed quantitatively and interview result was analyzed qualitatively. There were 30 students enrolled in second semester of GCS of Singapore in the 2017-2018 academic year and two English Lecturers who have been teaching in this institution. The participants of this research were taken by conducting purposive sampling technique (Cohen, Manion, Lecturer, Morrison, \& Lecturer, n.d.).The questionnaire is given to the thirty students and semi-structured interview is conducted to the two English lecturer of this institution. Descriptive and frequencies analyses were run in order to process the collected information. Qualitative analysis was conducted to analyze the responses from the interviews. The questionnaire had three main parts, the students' personal information, the learners' need for English materials and their perception of the English learning process in their institution.

\section{FINDINGS AND DISCUSSION}

\section{Students personal information}

The research participants were selected from students 30 second-semester students which consist of 17 females and 13 males. Half of them are eighteen years old, ten students are nineteen and five of them are twenty years old. Students were asked about their objective in learning English. Students who learn English for Studying requirement are 20 students (67\%), for working are 7 students (23\%), and 3 students (10\%) learn English to communicate with others. ICT students are taught by Indonesian Lecturer and Foreign Lecturer, then the language instruction which used by the Foreign lecturer in English and mostly the handbook of each subject use English. This could be the reason they rate this choice as such. Majority of students learn English started from elementary school (87\%), and three of them learn English when they were in junior high school (13\%).

\section{Students' need for learning English}

Regarding the students' need in English, half of them (50\%) chose that speaking is needed, followed by ten students (33\%) agreed that they need writing skills. There were three students $(10 \%)$ chose listening and two students $(7 \%)$ for reading. 


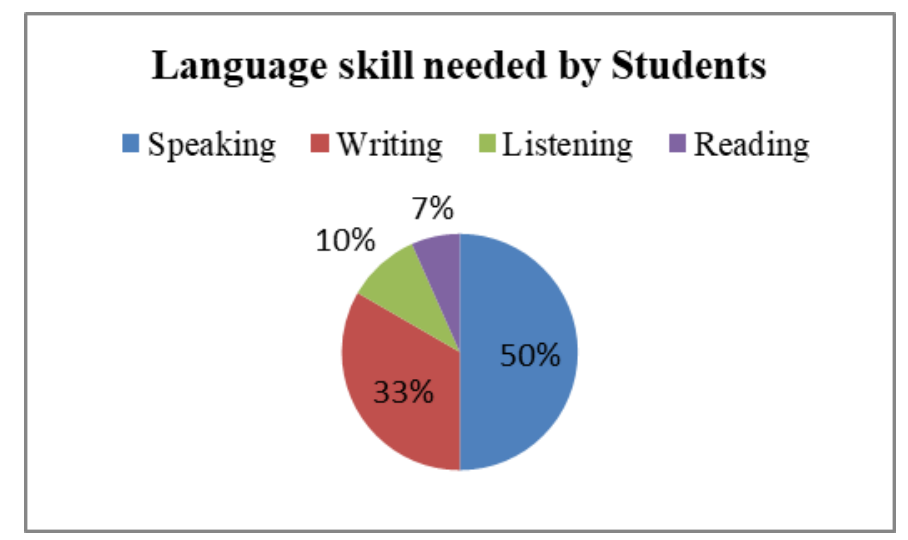

Figure 1. Language skills which needed by the Students

From figure 1, it can be seen that speaking is important for them. This institution exists based on collaboration UNM with GCS Singapore. Some of the lecturers come from Singapore and they use English as language instruction. Therefore, all the language skills are important especially speaking skill. Speaking was useful when they interacted with their lecturers from Singapore.

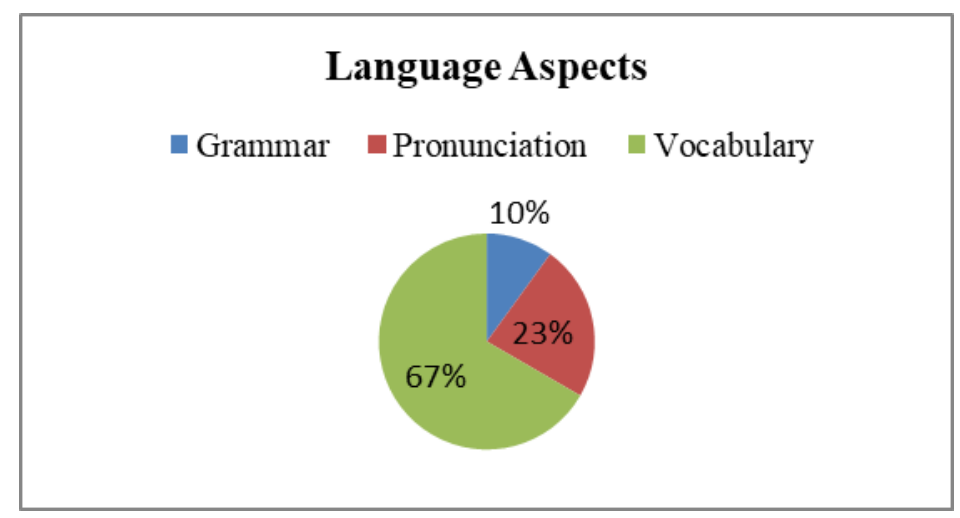

Figure 2. Language Aspects needed by the Students

Figure 2 shows that there were $67 \%$ of the students (20) need vocabulary, $23 \%$ of them (7) need pronunciation, and $10 \%$ need grammar. Vocabulary mastery will support the students to improve their speaking. It could be the reason most of the students need it. In writing skill, vocabulary is needed by the students to assist them in doing their final project. Moreover, they need speaking skill to do their final project by presenting the final report in front of their lecturer as final exam for them. 
Volume 4, Number 2, December 2018

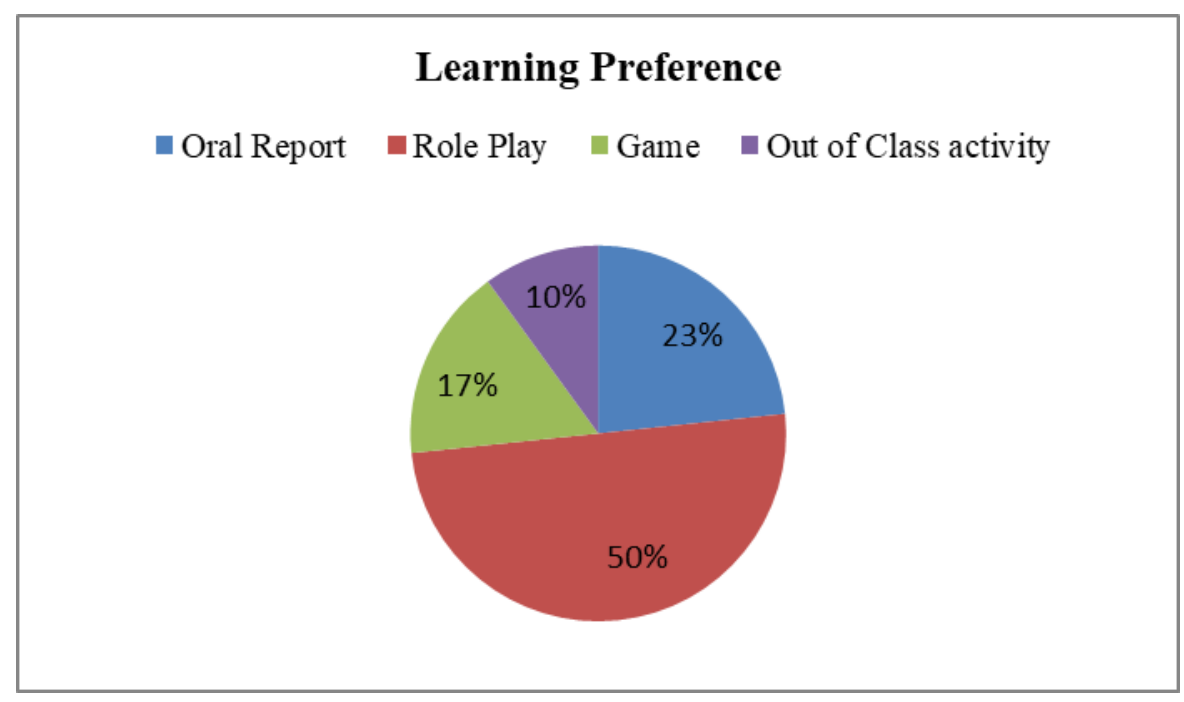

Figure 3. Students' Learning Preference

The students were also asked about their learning preference. There were 15 students $(50 \%)$ chose the option roleplay, 7 students $(23 \%)$ chose the oral report, 5 of them $(17 \%)$ prefer the game and other students $(10 \%)$ chose learn out of the class. It can be seen from the figure 3 that students prefer to practice their English by using Role play method and oral report. The Game is also needed to avoid boring situation in the classroom. This information is essential for the lecturers as course designer that can be included in English Teaching Materials.

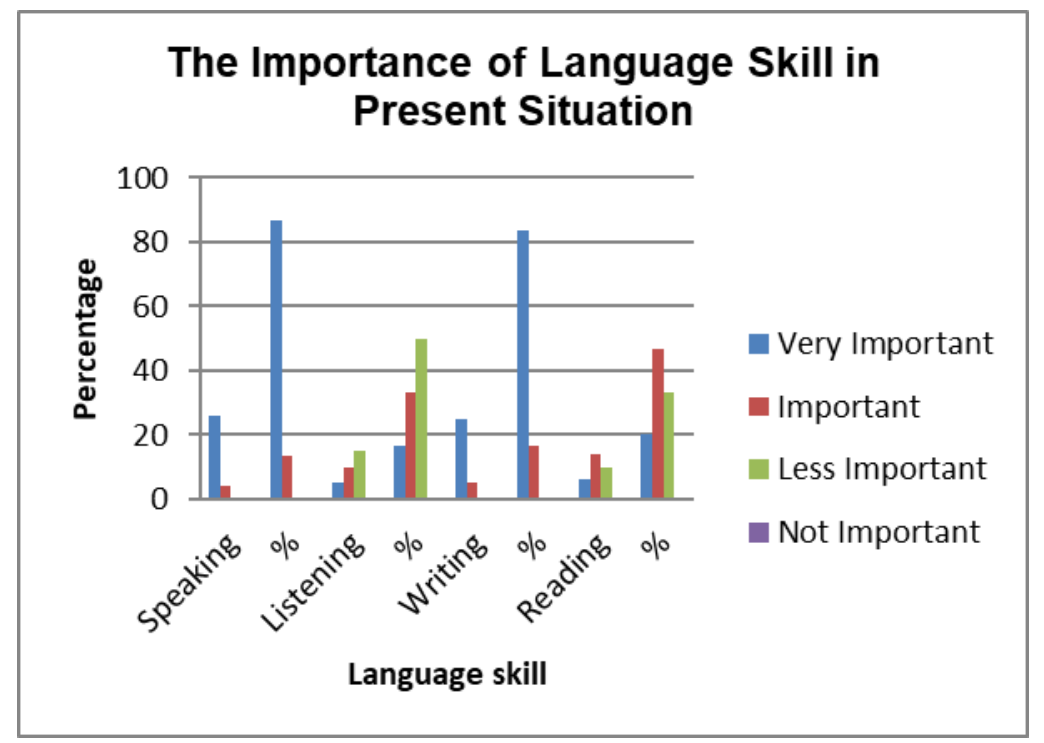

Figure 4. Student perception of the Importance of English Language Skill for their present Situation 
It was revealed that speaking and writing were deemed crucial skill as these two skills recorded the highest percentage (67\% respectively). The students of this institution required to master English especially speaking and writing. They need speaking skill to communicate to their lecturer from Singapore and they use English to present their final project at their final exam. Writing is also most important for them; it is because they need to finish their final report in English. Thus, Speaking and writing skills are two language skill most needed by them.

English is also needed for the students' future carrier. Students rated speaking and writing as the highest score. It can be seen from Figure 5.

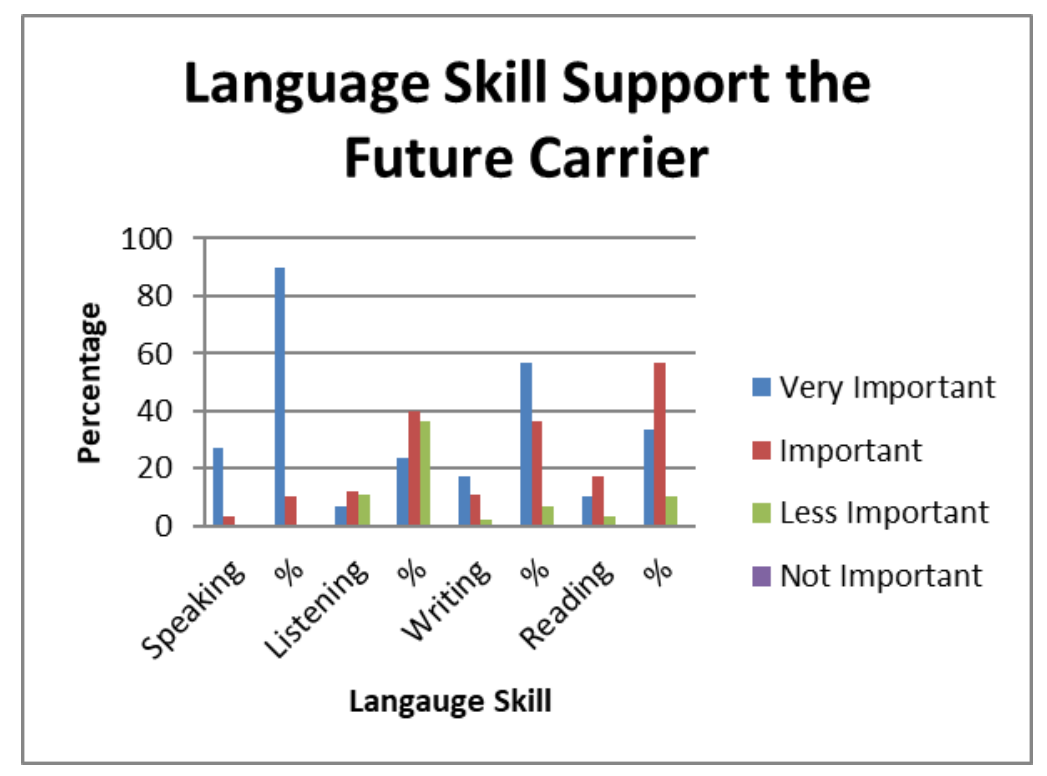

Figure 5. Student perception of the Importance of English Language Skill for their future carrier

From Figure 5, majority of the students were quite agreed that the use productive skills important in their future carrier. Moreover, there were 29 students $(97 \%)$ chose the option 'Very Important' and 17 students $(57 \%)$ chose the option 'important'. It indicated that the students predicted two of four language skill will be needed for their future. In other case that students mostly need speaking but it also the most difficult skill in English. Among the four-language skill, speaking rated as the highest score followed by reading as the difficult skill in English. Majority of the students faced difficulties in speaking $(90 \%)$ and reading $(53 \%)$. 


\section{Students perception about English Learning Process}

Students were also asked about the possession of English Module and all of them do not have the module as guidance in learning English. English Lecturers explained the material by using power point and after finishing the class the lecturers allowed the students to copy the file. As well as learning needs, all the students $(100 \%)$ stated that they would be more extremely interested in participating in a specific English course focusing its topics on ICT. Language instruction is used by the students combined into English and Indonesian language is favorites for the students $(100 \%)$. They prefer lecturer explained the materials in Indonesian and using English for the instruction. The two questions of the last part of the questionnaire were an openended question. They were about the students' perception of the English learning process and their suggestion for the future learning in this institution. Most of the students suggest that, learning English not only once a week but twice is better and they also need more practice than theory.

There were two lecturers as respondents of this research. Both of them are from English educational department. They teach English in this institution for more than two years. Based on the interview, the researcher found that most of the materials were not tailored for the English learning needs of the students in this institution. During the interview session with two English lecturers, they stated that students need to achieve their vocabulary mastery to aid the improvement of their language skill especially speaking and writing. Speaking is used to communicate with their lecturer from Singapore and writing skill is used to do their paper assignment. Both of skills are very useful for them to face final exam. The lecturer highlighted the fact that there was no permanent syllabus from the institution. The lecturer designs the teaching materials based on their own beliefs and ideas and did not based on students need. All the lecturers agreed that English is very important for them, not only in the classroom but also for

their future career. English subject should provide the materials based on students' needs and stakeholder has pivotal role in this part. By considering the result of this research, the institution should evaluate the policy about the English Material which has been taught in this institution. The new syllabus should be made and English Specific Purposes (ESP) is recommended.

\section{E. CONCLUSION}




\section{Sri D, Musdalifah M. Need Analysis on English Teaching Materials for ICT ...}

The result of this analysis study indicates that new English teaching materials focusing on speaking and listening skill should be developed at this institution. Moreover, these language skills are the most needed and urgent for the students whether in their present situation and their future carrier. The lecturers combined English and Indonesian language in teaching English and related to the teaching method, role-play is the most favorite then followed by oral-report, game and do some activities out the classroom to assist students in learning English. Teaching English with specific topic that related to the students' major would make them become more enthusiastic. This would be a recommendation to the institution, curriculum designer and course designer to consider the result of this research. The new syllabus and module should be recommended.

\section{REFERENCES}

Araminta., Lavinia D.W and Halimi, Sisilia S . (2015). Asean Economic Community 2015' Need Analysis of Universitas Indonesia's Engineering Students'. International Journal of Applied Linguistics, Vol. 5. No. 1 pp. 11-18.http://dx.doi.org/10.17509\%2Fijal.v5i1.841

Brown,J.D. (1995). The elements of Language Curriculum: a Systematic Approach to Program Development. Boston, Massachusetts: Heinle \& Heinle Publisher

Cohen, L., Manion, L., Lecturer, P., Morrison, K., \& Lecturer, S. (n.d.). (2007) Research Methods in Education.. Routledge

Dudley-Evans,T., \& St. John,M. J. (1998). Developments in English for Specific Purposes: A multi-disciplinary Approach. Cambridge, Cambridge University Press.

Hutchinson, T., \& Waters, A. (1987). English for Specific Purposes. Cambridge: Cambridge University Press.

Iwai, T., Kondo, K., Limm, S. J. D., Ray, E. G., Shimizu, H., and Brown, J. D. (1999). Japanese language needs analysis. Retrieved online on 10 December 2009 from: http://www.nflrc.hawaii.edu/Networks/NW13/NW13.pdf

Johns, A. (1991). English for specific purposes: its history and contribution. In Celce-Murcia, M. (Ed). Teaching English as a second or foreign language (pp.67-77). Boston, MA: Heinle \& Heinle. 
Volume 4, Number 2, December 2018

Kaur, S., Chairperson, P., Language, E., Section, S., English, T., Languages, O., ... Language, S. (2010). Language Needs Analysis of Art and Design Students: Considerations for ESP Course Design. ESP World, $9(2$ (28)), 1-16.

Kim, Hyun Hyo. (2013). Need Analysis for English for Specific Purposes course Development for Engineering in Korea. International Journal of Multimedia and Ubiquitous Engineering. Vol.8, No. 6. pp. 279-288. http:// dx.doi.org/10.14257/ijmue.2013.8.6.28

Li, J. (2014). Needs Analysis of Business English Undergraduates and the Implications to Business English Curriculum Design. Advances in Language and Literary Studies, 5(4). https://doi.org/10.7575/aiac.alls.v.5n.4p.33

Nunan, D. (1994). The learner-centered curriculum. Cambridge: Cambridge University Press.

Robinson, P. (1991)..ESP Today: A Practitioner's Guide. Hemel Hempstead: Prentice Hall. 